DOl 10.15826/Lurian.2020.1.1.3

УДК 616.89

\title{
Greetings From the American Psychological Association
}

\section{Neuropsychology: Reaching a Promise Land for Psychology}

\author{
Antonio E. Puente \\ $125^{\text {th }}$ President of the American Psychological Association, \\ University of North Carolina, \\ USA, Wilmington
}

\section{Приветствие от Американской психологической ассочиации}

\section{Нейропсихология: земля обетованная для психологии}

\author{
Антонио Э. Пуэнте \\ 125-й президент Американской психологической ассоциации, \\ Университет Северной Каролины, \\ США, Вилмингтон
}

Corresponding author. E-mail: antonioenriquepuente@gmail.com

For far too long psychology in the east and west have not interfaced sufficiently. With the globalization of thought, thinking, brain, mind and consciousness the two historical powers in the history of psychology - Russia and the United States have no choice but to join forces to bring the best that these two approaches to thinking about psychology and the world's problems. This is a time for unification and amalgamation of ideas, systems and forces as a means to become a stronger and more applicable psychology. Towards this goal, neuropsychology is the best suited specialty within psychology to bridge this existing gap. The tensions between ideologies do little to address the grave and impending problems facing all of us. From climate change to overpopulation to continuing misunderstandings between people and peoples are some of the pressing issues in which psychology, and, specifically, neuropsychology may bring to furthering understanding and providing viable solutions.

There is no better solution than to bring psychology back to the roots from both Russia, via Ivan Pavlov, and the United States, via William James. Pavlov seminal book, Conditioned Reflexes provides us with a glimpse of what psychology is and should be. The subtitle provides the most comprehensive glimpse of his thinking- An investigation of the physiological activity of the cerebral cortex. Surprisingly, later reproductions of the original publication 
leave off the subtitle suggesting, especially for the behaviorally focused western psychologists, that the focus of the book is about "Pavlovian conditioning" or a form of learning.

Similarly, in reviewing William James's book, Psychology, the first English language textbook in psychology, the Table of Contents similarly provide us where psychology was founded. The book is nothing more than an introduction to neuropsychology textbook. By chapter three focus is being placed on specific and important areas of the brain. Within the first few pages of that chapter, the basic concepts of cerebral hemispheres are outlined. Interestingly, the discoverer of the split brain phenomena and psychology's first Nobel Prize winner, Roger W. Sperry, was introduced to psychology both by this book and one of James' student.

The question remains; how is one to bridge the powerful origins of Russian and American psychology? Since the founding of psychology in the late 1800s, the distance between Russian and western psychology has been much larger than the geographic distance between the two.

The most likely person and theory to bring psychology back to its roots and to bridge the two historically competing perspectives is the romantic science of Alexander Luria. In doing so, three predictions are made:

1. The specialty of clinical neuropsychology, one of the largest, fastest growing and most important specializations in psychology, has yet to realize the value it can provide psychology and health. The gulf between medicine and psychology has been historically so wide that a Cartesian dualism has penetrated both the thinking of physicians and psychologists as well as even of the typical citizen in our societies. The idea of bringing the two perspectives from the east and the west, together will go a long ways in crossing this illusory gulf.

2. As our world(s) shrink and national boundaries become artificial and the interface between people(s) and culture(s) become the rule and not the exception, a socio-historical-contextual perspective becomes the sole solution to narrow, if not, completely eliminate the perceptual differences that have prevented more universal understanding and solutions. In doing so, neuropsychology then becomes the conduit for psychology to fill the gaps that historically powerful institutions have yet to address successfully.

3. The concept of a romantic science is the most robust approach to bridging the subjective with the objective, the qualitative with the quantitative, and ignorance with understanding. In interjecting the concept of a romantic science, the interfacing of historically and diametrically opposed paradigms brings forth new possibilities. In doing so, the hope and direction that has been missing in psychology may be restated.

As the $125^{\text {th }}$ president of the American Psychological Association, I am honored and privileged to be part of the historical event - the founding of the Lurian Journal.

Original manuscript received January 31, 2020 Revised manuscript accepted February 15, 2020

To cite this article: Puente, A.E. (2020). Neuropsychology: Reaching a promise land for psychology. Lurian Journal, 1 (1), 18-19. DOI: 10.15826/Lurian.2020.1.1.3 